\title{
Non-pupillary block angle-closure mechanisms: a comprehensive analysis of their prevalence and treatment outcomes
}

\author{
Mecanismos de fechamento angular sem bloqueio pupilar: análise de prevalência e resultados terapêuticos
}

Daniela L. M. Junqueira ${ }^{1}$, Vitor G. Prado ${ }^{1,2}$, Flavio S. Lopes ${ }^{1,2}$, Luis Gustavo Biteli, ${ }^{1,2}$, Syril Dorairaj ${ }^{3}$, Tiago S. Prata ${ }^{1,2}$

\begin{abstract}
Purpose: To assess the prevalence and treatment outcomes of angle-closure mechanisms other than pupillary block in a population of Brazilian patients.

Methods: A retrospective chart review was conducted to evaluate patients who had undergone laser peripheral iridotomy (LPI) due to occludable angles at a single institution between July 2009 and April 2012. An occludable angle was defined as an eye in which the posterior trabecular meshwork was not visible for $\geq 180^{\circ}$ on dark-room gonioscopy. Key exclusion criteria were any form of secondary glaucoma and the presence of $>90^{\circ}$ of peripheral anterior synechiae. Collected data were age, race, gender, angle-closure mechanism (based on indentation goniocopy and ultrasound biomicroscopy), intraocular pressure (IOP), number of antiglaucoma medications and subsequent management during follow-up. If both eyes were eligible, the right eye was arbitrarily selected for analysis.

Results: A total of 196 eyes of 196 consecutive patients (mean age $58.3 \pm 11.6$ years) who underwent LPI were included. In most of the patients [86\% (169 patients; 133 women and 36 men]), LPI sucessfully opened the angle. Mean IOP was reduced from $18.3 \pm 6.4 \mathrm{mmHg}$ to $15.4 \pm 4.5 \mathrm{mmHg}$ after $\mathrm{LPI}(\mathrm{p}<0.01)$. Among the 27 patients with persistent occludable angles, the most common underlying mechanisms were plateau iris (56\%) and lens-induced component (34\%). Most of these patients (85\%) were treated with argon laser peripheral iridoplasty (ALPI): approximately $90 \%$ showed non-occludable angles following the laser procedure (mean IOP reduction of 18.9\%), with no significant differences between patients with plateau iris and lens-induced components ( $p=0.34$; mean follow-up of 11.4 \pm 3.6 months).
\end{abstract}

Conclusions: Our findings suggest that, in this population of Brazilian patients, several eyes with angle closure were not completely treated with LPI. In the present large case series involving middle-age patients, plateau iris was the leading cause of persistent angle closure and was effectively treated with ALPI. A detailed eye examination with indentation gonioscopy should always be performed after LPI to rule out persistent angle closure due to non-pupillary block mechanisms.

Keywords: Angle closure; Non-pupillary block mechanisms; Iris diseases; Iris/ pathology; Iridectomy; Treatment outcome

\section{RESUMO}

Objetivo: Reportar a prevalência e os resultados terapêuticos em casos de fechamento angular por outros mecanismos além de bloqueio pupilar em uma população de pacientes brasileiros.

Método: Realizou-se um estudo retrospectivo para avaliar pacientes apresentando ângulo oclusível submetidos à iridotomia periférica a laser (LPI), em uma única instituição, entrejulho/2009 e abril/2012. Ângulo oclusível foi definido pela não observação do trabeculado posterior em mais de $180^{\circ}$ à gonioscopia sem identação. Olhos com glaucomas secundários ou $>90^{\circ}$ de sinéquia anterior periférica foram excluídos. Foram coletados os seguintes dados: idade, raç, sexo, mecanismo de fechamento angular (com base na gonioscopia e biomicroscopia ultrassônica), pressão intraocular (PIO), número de medicações antiglaucomatosas e manejo subsequente durante o seguimento. Sempre que ambos os olhos eram elegíveis, o olho direito foi escolhido arbitrariamente para análise.

Resultados: Foram incluidos 196 olhos de 196 pacientes (58,3 $\pm 11,6$ anos) que foram submetidos à LPI. Na maioria dos casos [86\% (169 pacientes; 133 mulheres e 36 homens), a LPI foi capaz de abrir o ângulo. A PIO média foi reduzida de 18,3 \pm 6,4 para 15,4 $\pm 4,5 \mathrm{mmHg}$ após a LPI $(p<0,01)$. Entre os 27 casos que persistiram com ângulo oclusível, os mecanismos mais comuns envolvidos foram íris em platô (56\%) e induzido por componente cristaliniano (34\%). A maioria desses casos (85\%) foram tratados com iridoplastia periférica a laser (ALPI). Aproximadamente $90 \%$ tornaram-se não oclusíveis após a ALPI (redução média da PIO de 18,9\%), não havendo diferença significativa entre os pacientes com componentes de íris em platô ou cristaliniano ( $p=0,34$; seguimento médio de 11,4 $\pm 3,6$ meses).

Conclusões: Nossos resultados sugerem que, nessa população de pacientes brasileiros, parte dos olhos com fechamento angular não foi completamente tratada com LPI. Nesta série de pacientes de meia-idade, a presença de íris em platô foi a principal causa defechamento angularpersistente, sendo efetivamente tratada com ALPI. Acreditamos que um exame gonioscópico detalhado deva ser realizado após a LPI para descartar fechamento angular persistente por outros mecanismos que não bloqueio pupilar.

Descritores: Fechamento angular; Bloqueio pupilar; Doenças da íris; Irís/patologia; Iridectomia; Resultado de tratamento

\section{INTRODUCTION}

Relative pupillary block (PB) is considered to be the primary mechanism for angle closure(1-3). Although laser peripheral iridotomy (LPI) remains the cornerstone of angle-closure management, it does not widen the angle in all cases, as approximately $20 \%-30 \%$ of these patients continue to exhibit appositional angle closure in the presence of a patent iridotomy ${ }^{(1-3)}$. In these cases, non-PB mechanisms, such as lens-induced, plateau iris, and peripheral angle crowding, may be involved ${ }^{(4-7)}$. Argon laser peripheral iridoplasty (ALPI) and lens extraction have been proposed as effective procedures to manage eyes with persistent occludable angles ${ }^{(8-10)}$.

While dealing with cases of primary angle closure (with or without glaucoma), identification of the underlying mechanism is of the utmost importance because each may follow a different course and require a different treatment approach. Although there is extensive information in the literature regarding the main etiologies and guidelines
Submitted for publication: May 12, 2014

Accepted for publication: October 21, 2014

Study conducted at Universidade Federal de São Paulo.

Glaucoma Unit, Hospital Medicina dos Olhos, Osasco, SP, Brazil.

2 Universidade Federal de São Paulo, São Paulo, SP, Brazil.

${ }^{3}$ Mayo Clinic, Jacksonville, Florida.
Funding: No specific financial support was used for this study.

Disclosure of potential conflicts of interest: None of the authors have any potential conflicts of interest to disclose.

Corresponding author: Tiago Santos Prata. Departamento de Oftalmologia - UNIFESP/EPM - Rua Botucatu, 821-São Paulo, SP - 04023-062 - Brazil - E-mail: tiagoprata@ig.com.br

Approved by the following Research Ethics Committee: Sociedade Brasileira e Japonesa de Beneficência/Hospital Santa Cruz, São Paulo, sob o número (178.759). 
for management of primary angle closure in Asian, North American, and European populations, there are scant data with regard to South American patients $s^{(2,11-16)}$. In the present study, we investigated the prevalence and treatment outcomes of angle-closure mechanisms other than pupillary block in a population of Brazilian patients.

\section{METHODS}

\section{Patients}

After Institutional Review Board approval, a comprehensive chart review was conducted to evaluate consecutive patients who underwent LPI due to occludable angles at a single institution between July 2009 and April 2012. An occludable angle was defined as an eye in which the posterior trabecular meshwork was not visible for $\geq 180^{\circ}$ without indentation on dark-room gonioscopy. Because some eyes may not have irido-trabecular contact even when the trabecular meshwork is not visible, an additional requirement was that corneal and iris beams of light should merge during non-indentation gonioscopy (in order to confirm the presence of irido-trabecular contact). Eyes with previous incisional surgery, with $>90^{\circ}$ of peripheral anterior synechiae (PAS), ocular trauma, uveitis, or any other form of secondary glaucoma were excluded.

\section{Data Collection AND PROCEDURES}

Data collected were age, gender, race, presence of glaucoma, pre- and post-laser intraocular pressure (IOP), number of antiglaucoma medications, angle status and underlying angle-closure mechanisms as determined by gonioscopy and subsequent management during follow-up. All laser procedures, pre- and post-laser gonioscopy assessments and IOP measurements were performed by two experienced glaucoma specialists (LGB and TSP). In all cases, dark-room gonioscopy was performed with and without indentation using a Posner four-mirror lens (Ocular Instruments Inc., Bellevue, WA, USA). The light beam was set at 1-2 $\mathrm{mm}$ to avoid illuminating the pupil, and the most posterior region of the anterior chamber angle that was visible without indentation was determined. The angle was classified as occludable or non-occludable based on the previously mentioned definition. Regarding ALPI parameters, a 500 micron spot, 500 ms duration and $250 \mathrm{~mW}$ power were routinely used, which could vary according to iris pigmentation and tissue response. The center of a Goldmann 3 mirror lens was used and, after the procedure, prednisolone acetate $1 \%$ was administered four times per day for one week.

In brief, the main mechanisms of angle closure could be described as follows: (1) relative pupillary block, which results from increased resistance to the flow of aqueous humor between the pupillary portion of the iris and the anterior lens surface; (2) plateau iris (Figure $1 \mathrm{~A})$, which results from an abnormal anatomical configuration/relationship of the anterior chamber angle and ciliary body and is usually confirmed after a LPI failure; and (3) lens induced (Figure 1 B), which involves a normal or large lens pushing the iris forward and resulting in a reduced anterior chamber volume and angle-closure ${ }^{(4-7)}$.

On indentation gonioscopy, eyes with a relatively deep central anterior chamber and irido-trabecular contact after LPI in which the "double hump sign" was identified were considered to exhibit plateau
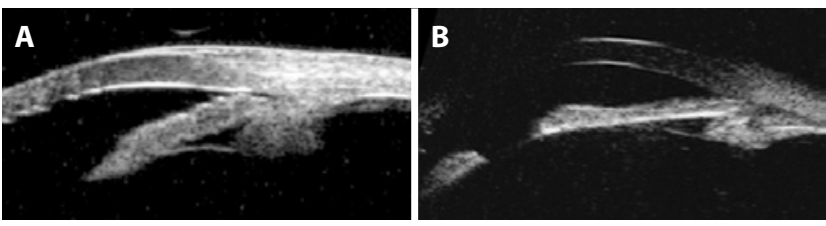

Figure 1. Ultrasound biomicroscopy images of two patients with persistent occludableangles following laserperipheral iridotomy dueto plateau iris $(A)$ and lens-induced component (B). iris component. On the other hand, those with a shallower central anterior chamber in which the iris appeared to drape the anterior surface of the lens, giving rise to a "volcano-like" configuration were considered to exhibit the lens-induced component ${ }^{(5,8)}$. Ultrasound biomicroscopy was used in most cases of persistent occludable angles following LPI.

\section{Statistical analysis}

Descriptive analysis was used to present demographic and clinical data. D'Agostino-Pearson's test was performed to determine whether the data had a normal distribution. The paired-samples T-test was used to compare continuous normally distributed variables, while the Wilcoxon signed-rank test was used to compare those that were non-normally distributed. Baseline IOP was determined as the average of three measurements prior to the laser procedures. Post-laser IOP was based on a single measurement (IOP measurement on each patient's last visit). The treatment regimen was not altered until the final follow-up visit. If both eyes were eligible for inclusion, the right eye was arbitrarily chosen for analysis. Statistical significance was set at $p<0.05$. Computerized analysis was performed using MedCalc software (MedCalc Inc., Mariakerke, Belgium).

\section{RESULTS}

A total of 196 eyes of 196 consecutive patients (mean age 58.3 \pm 11.6 years; 133 women and 36 men) who underwent LPI were included. Primary angle-closure suspects/primary angle closure constituted $54 \%$ of the cases, primary angle-closure glaucoma $40 \%$ and acute angle-closure glaucoma 6\%. In most of the cases (86\%), LPI successfully opened the angle. Mean IOP was reduced from $18.3 \pm 6.4$ to $15.4 \pm 4.5 \mathrm{mmHg}$ after $\mathrm{LPI}(\mathrm{p}<0.01)$.

Forty-one eyes (27 patients) had persistent occludable angles after LPI, comprising approximately $14 \%$ of the cases that had previously undergone iridotomy. Among these cases, the most common angle-closure mechanisms were plateau iris (56\%) and lens-induced component (34\%). Regarding the remaining 10\% of the cases of persistent occludable angles (without characteristics of plateau iris or lens-induced component), most eyes had a thick peripheral iris with prominent circumferential folds, occupying a large proportion of the angle, and were classified as thick peripheral iris roll (or peripheral iris crowding) $)^{(4,5)}$. Patients with plateau iris were mostly women (75\%) and younger (mean age 55.3 years) than those with lens-induced component (mean age 64.8 years; $30 \%$ women; $p \leq 0.03$ ). None of the patients were taking pilocarpine prior to the laser procedures. Table 1 summarizes the clinical characteristics of these patients.

Most of these cases of persistent occludable angles following LPI were treated with laser iridoplasty (85\%). Regarding the four other patients, two had cataracts associated with low visual acuity and

Table 1. Characteristics of patients with persistent occludable angle due to non-pupillary mechanisms ${ }^{*}$

\begin{tabular}{lc}
\hline Variables & Patients (n=27) \\
\hline Mean age (years) & $58.9 \pm 11.8$ \\
Gender \% (men/women) & $44 / 56$ \\
Race \% (white/black/asian) & $78 / 15 / 7$ \\
Presence of glaucoma (\%) & $63 \%$ \\
Angle-closure mechanisms \% (PIC/LIAC/others) & $56 / 34 / 10$ \\
Mean IOP before ALPI (mmHg) & $17.9 \pm 4.9$ \\
Mean IOP after ALPI (mmHg) & $14.5 \pm 4.2$ \\
\hline
\end{tabular}

*Data are presented as mean \pm standard deviation whenever indicated. $\mathrm{ALPI}=$ argon laser peripheral iridoplasty; $I \mathrm{OP}=$ intraocular pressure; $L I A C=$ lens-induced angle closure; $\mathrm{PIC}=$ plateau iris component. 
underwent phacoemulsification with intraocular lens implantation, and two were treated with pilocarpine at night-time. Treatment regimens were not changed until the final follow-up visit (mean length of follow-up, $11.4 \pm 3.6$ months; mean number of antiglaucoma medications, $1.7 \pm 1.3$ ). Approximately $90 \%$ of the cases showed non-occludable angles following ALPI. Intraocular pressure was significantly reduced from $17.9 \pm 4.9$ to $14.5 \pm 4.2(p<0.01)$ with no significant differences between patients with plateau iris and lens-induced components $(p=0.34)$. Although some cases of photophobia were noted, there were no cases of peripheral anterior synechiae formation.

\section{DISCUSSION}

Recent estimates show that $>67$ million individuals around the world have glaucoma. Although open-angle glaucoma comprises approximately two-thirds of these cases, angle-closure glaucoma is present in one-half of patients who are blind from the disease $e^{(17,18)}$. In addition, in populations such as Chinese, Indian and Mongolian, the prevalence of angle-closure glaucoma is as high or even higher than that of open-angle glaucoma ${ }^{(16,17,19-22)}$. Therefore, angle-closure glaucoma has a considerable impact on daily clinical practice. Evaluating a large series of patients with primary angle closure (with and without glaucoma), we determined the most frequent underlying angle-closure mechanisms and the outcomes of laser treatment (both iridotomy and iridoplasty). To the best of our knowledge, the present study is the first to report on such findings in a large sample of Brazilian patients.

At this point, we believe it is important to discuss the clinical implications of our findings. Treatment of primary angle-closure is directed toward two goals: to eliminate the mechanism of angle closure and to control IOP elevation ${ }^{(14)}$. Previous studies have shown that following LPI, approximately $20 \%-30 \%$ of these patients continue to exhibit appositional angle closure in the presence of a patent iridotomy ${ }^{(1-3)}$. In our study, we found a slightly higher success rate, as $86 \%$ of the eyes showed non-occludable angles following LPI. Although these differences may be the result of a lower prevalence of non-pupillary block mechanisms in our study population, we believe that age (the mean age of our study population was $<60$ years and, thus, the prevalence of lens-induced component was likely low) and the fact we excluded patients with $>90^{\circ}$ of PAS should be taken into consideration.

Although laser iridotomy is currently the first line of treatment, many eyes will continue to exhibit appositional angle-closure, and an additional treatment option may be necessary ${ }^{(2,3)}$. In the present large consecutive series, ALPI was highly effective in eliminating residual appositional angle closure caused by mechanisms other than pupillary block. In addition, we documented a 20\% IOP reduction on average. Our results not only confirm the important role of ALPI in cases of plateau iris ${ }^{(8)}$, but also suggest that it may be an effective alternative in cases involving lens-induced component. We believe that this is clinically meaningful, as not every case of lens-induced angle closure necessarily coexists with a symptomatic cataract. In fact, this appears to be the case of our study population, which is mostly composed of middle-aged patients. It is noteworthy that ALPI has also been successfully used as an initial treatment to break acute phacomorphic attacks ${ }^{(23)}$. Regarding the few cases in which ALPI was not effective in our series, the proportion was similar between eyes with plateau iris and lens-induced component, and we could not identify any predictors of success or failure. As additional findings, our plateau iris patients tended to be women and younger than those with lens-induced component, and ALPI effectiveness was similar in both angle-closure mechanisms during an average follow-up period of almost one year.

We believe it is important to stress some specific characteristics and limitations of our study. First, our study is based on retrospective data and had a relative short follow-up period. Therefore, success rates, especially related to ALPI, may have been positively influenced. Second, a subjective gonioscopic criterion was adopted for each angle-closure mechanism. Moreover, ultrasound biomicroscopy images were available for most patients with persistent occludable angles following LPI, but not for every patient. These missing ultrasound biomicroscopy data could have added useful information (such as anterior chamber depth measurements) to our results. Third, ideally, different examiners should have performed pre- and post-laser gonioscopic examinations. However, the present study was retrospective, and each glaucoma specialist performed not only the laser procedure, but also baseline and post-laser gonioscopy assessments. This potential bias of data collection should be considered while interpreting our results. Fourth, although Brazil is a multiracial country, our patients were enrolled from just one center (in the city of Osasco, São Paulo). Therefore, our results may not be representative of the entire Brazilian population. However, it should be emphasized that São Paulo has a high rate of immigration and, as a result, its population is composed of individuals from all over the country.

In conclusion, our findings suggest that, in this population of Brazilian patients, several eyes with angle closure were not completely treated with LPI. In the present large series of middle-aged patients, plateau iris was the leading cause of persistent angle closure and was effectively treated with ALPI. A detailed eye examination with indentation gonioscopy should always be performed after LPI to rule out persistent angle closure due to non-pupillary block mechanisms.

\section{REFERENCES}

1. He M, Friedman DS, Ge J, Huang W, Jin C, Lee PS, et al. Laser peripheral iridotomy in primary angle-closure suspects: biometric and gonioscopic outcomes: the Liwan Eye Study. Ophthalmology. 2007;114(3):494-500.

2. Thomas R, Arun T, Muliyil J, George R. Outcome of laser peripheral iridotomy in chronic primary angle closure glaucoma. Ophthalmic Surg Lasers. 1999;30(7):547-53. 3. Chandler PA. Narrow-angle glaucoma. Arch Ophthalmol. 1952;47(6):695-716.

4. Prata TS, Biteli LG, Dorairaj S. Angle closure associated with a cobblestone iris configuration: clinical and imaging description. J Glaucoma. 2013;22(9):36-7.

5. Shabana N, Aquino MC, See J, Ce Z, Tan AM, Nolan WP, et al. Quantitative evaluation of anterior chamber parameters using anterior segment optical coherence tomography in primary angle closure mechanisms. Clin Experiment Ophthalmol. 2012:40(8):792-801.

6. Tornquist R. Angle-closure glaucoma in an eye with a plateau type of iris. Acta Ophthalmol (Copenh). 1958;36(3):419-23.

7. Prata TS, Dorairaj S, De Moraes CG, Tello C, Liebmann JM, Ritch R. Indentation slitlamp-adapted optical coherence tomography technique for anterior chamber angle assessment. Arch Ophthalmol. 2010;128(5):646-7.

8. Ritch R, Tham CC, Lam DS. Long-term success of argon laser peripheral iridoplasty in the management of plateau iris syndrome. Ophthalmology. 2004;111(1):104-8.

9. Ming Zhi Z, Lim AS, Yin Wong T. A pilot study of lens extraction in the management of acute primary angle-closure glaucoma. Am J Ophthalmol. 2003;135(4):534-6.

10. Gunning FP, Greve EL. Lens extraction for uncontrolled angle-closure glaucoma: long-term follow-up. J Cataract Refract Surg. 1998; 24(10):1347-56.

11. Sakata K, Sakata LM, Sakata VM, Santini C, Hopker LM, Bernardes R, et al. Prevalence of glaucoma in a South brazilian population: Projeto Glaucoma. Invest Ophthalmol Vis Sci. 2007:48(11):4974-9.

12. Nolan WP, Foster PJ, Devereux JG, Uranchimeg D, Johnson GJ, Baasanhu J. YAG laser iridotomy treatment for primary angle closure in east Asian eyes. $\mathrm{Br} J$ Ophthalmol. 2000;84(11):1255-9.

13. Cumba RJ, Nagi KS, Bell NP, Blieden LS, Chuang AZ, Mankiewicz KA, et al. Clinical outcomes of peripheral iridotomy in patients with the spectrum of chronic primary angle closure. ISRN Ophthalmol. 2013 26;2013:828972.

14. American Academy of Ophthalmology. American Academy of Ophthalmology Glaucoma Panel. Preferred Practice Pattern Guidelines: Primary Angle Closure. San Francisco, Calif, USA: American Academy of Ophthalmology; 2010.

15. See JL, Aquino MC, Aduan J, Chew PT. Management of angle closure glaucoma. Indian J Ophthalmol. 2011;59 Suppl:S82-7.

16. Foster PJ, Johnson GJ. Glaucoma in china: how big is the problem? British Journal of Ophthalmology. 2001;85(11):1277-82.

17. Congdon N, Wang F, Tielsch JM. Issues in the epidemiology and population-based screening of primary angle-closure glaucoma. Surv Ophthalmol. 1992;36(6):411-23.

18. Day AC, Baio G, Gazzard G, Bunce C, Azuara-Blanco A, Munoz B, et al. The prevalence of primary angle closure glaucoma in european derived populations: A systematic review. Br J Ophthalmol. 2012;96(9):1162-7.

19. Quigley HA, Congdon NG, Friedman DS. Glaucoma in China (and worldwide): chan- 
ges in established thinking will decrease preventable blindness. $\mathrm{Br} J$ Ophthalmol. 2001:85(11):1271-2.

20. Shen SY, Wong TY, Foster PJ, Loo JL, Rosman M, Loon SC, et al. The prevalence and types of glaucoma in malay people: the Singapore Malay eye study. Invest Ophthalmol Vis Sci. 2008;49(9):3846-51

21. Tarongoy $\mathrm{P}, \mathrm{Ho} \mathrm{CL}$, Walton DS. Angle-closure glaucoma: the role of the lens in the pathogenesis, prevention, and treatment. Surv Ophthalmol. 2009; 54(2):211-25.
22. Amerasinghe N, Zhang J, Thalamuthu A, He M, Vithana EN, Viswanathan A, et al. The heritability and sibling risk of angle closure in Asians. Ophthalmology. 2011;118(3): 480-5.

23. Tham CC, Lai JS, Poon AS, Chan JC, Lam SW, Chua JK, et al. Immediate argon laser peripheral iridoplasty (ALPI) as initial treatment for acute phacomorphic angle-closure (phacomorphic glaucoma) before cataract extraction: a preliminary study. Eye (Lond). 2005:19(7):778-83.

\title{
XXII Curso Regional Pan-Americano de Oftalmologia
}

\author{
21 a 22 de março de 2015 \\ Hard Rock Hotel \\ Cidade do Panamá - Panamá
}

Informações:

Site: http://www.paao.org/index.php?component=com_articles\&id_art=90\#registration 